\author{
DEPARTMENT OF THE INTERIOR \\ UNITED STATES GEOLOGICAL SURVEY
}

\title{
AEROMAGNETIC MAP OF THE GERMANTOWN AND PART OF THE POOLESVILLE QUADRANGLES, MONTGOMERY AND \\ FREDERICK COUNTIES, MARYLAND \\ By
}

Jean Blanchett, N. S. Tyson, and E. F. McGowan

GEOPHYSICAL INVESTIGATIONS

MAP GP-394

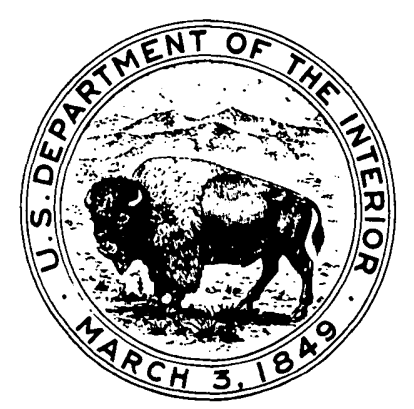

PUBLISHED BY THE U. S. GEOLOGICAL SURVEY

WASHINGTON, D. C. 